\title{
Coding of Tissue and Cell Preparations Using Eurocode
}

\author{
Ralf Knels $^{a}$ Kirstin Stüpmann ${ }^{b} \quad$ Axel Pruß $^{c}$ Jan Klerke ${ }^{d} \quad$ Joachim Kardoeus $^{\mathrm{e}}$ Jens Hiller $^{f}$ \\ ${ }^{a}$ Eurocode International Blood Labeling System e.V., Dresden, Germany; \\ ${ }^{b}$ German Red Cross Blood Donation Service Mecklenburg-Vorpommern, Rostock, Germany; \\ c University Tissue Bank, Institute of Transfusion Medicine; Charité - University Medicine Berlin, Berlin, Germany; \\ dGerman Society for Tissue Transplantation (DGFG), Hanover, Germany; \\ e Department of Medicine, University Münster, Münster, Germany; \\ ${ }^{\mathrm{f}}$ Institute of Transfusion Medicine; University Hospital Hamburg-Eppendorf, Hamburg, Germany
}

\section{Keywords}

SEC $\cdot$ Eurocode $\cdot$ Tissue $\cdot$ Cell preparations .

Coding systems · Traceability · European Directives . 2006/86/EC · 2015/565/EC

\section{Summary}

Traceability of products requires their unique identification. In Germany blood products have been encoded by Eurocode since 1998. EU Directives 2004/23/EC, 2006/86/ EC and 2015/565/EC demanded unique identification and safe traceability procedure also for tissues and cells. Eurocode IBLS e.V. and the German Society of Transfusion Medicine and Immunohematology (DGTI) working parties 'Tissue Preparations' and 'Automation and Data Processing' supplemented the already available Eurocode nomenclature for blood products with further data structures for tissue preparations. Based on an agreement with the European Commission, Eurocode Product Codes can be used as 'product number' within the Single European Code (SEC). Several data elements of Eurocode can be used to create the complete SEC data structure, except the tissue establishment number. This can be found on the EU Coding Platform in the internet. Consequently, existing software and labeling solutions in Eurocode format could be easily upgraded with SEC.

(c) 2017 S. Karger GmbH, Freiburg

\section{Introduction}

Eurocode International Blood Labelling System e.V. (Eurocode IBLS) was founded in 1998 and is a non-profit organization under German Tax Law. Eurocode IBLS is responsible for the maintenance of Eurocode, which is established today as a coding system for products of human origin mainly in Germany. The technical committee strove to incorporate current ISO standards and other standardizations during the development of the code structures.

As a result of HIV and HCV transmissions during the 1990s, today the necessity of clear identification and traceability is widely accepted for material of human origin. The minimum information required is a unique identification number for every preparation which can be tracked back to the original donor. End users need further information about the product; thus Eurocode provides additional data elements. All Eurocode product codes for tissue and cell preparations are matched with the product codes of the EU Tissue and Cell Product Compendium (EUTC) [1-3]. A contract between EU and Eurocode guarantees the consecutive matching of new codes by Eurocode and their publication on the EU Coding Platform [4]. Unfortunately, the European requirements regarding structure and content of the traceability information differ between blood products such as red cells or platelet products (described in 2002/98/EC [5]) and other cell preparations or tissues (described in 2006/86/EC [2]). In Germany, further confusion is caused by the fact that, unlike in other European countries, hematopoietic progenitor cells have to be encoded like tissues.

All details about Eurocode data structures can be found in the Eurocode IBLS Technical Specification [6].

\section{Aims of Eurocode IBLS}

The aims of Eurocode IBLS are enlisted in $₫ 3$ of the Eurocode IBLS Statute [7]. The basic aim is to improve the quality and safety of transfusion and transplantation medicine by creating internationally standardized data structures for the encoding of biologicals

\section{KARGER}

() 2017 S. Karger GmbH, Freiburg

Fax +497614520714 


\begin{tabular}{|c|c|c|c|c|c|c|c|c|}
\hline & \multicolumn{4}{|c|}{ Unique Product Identification Number } & \multicolumn{2}{|c|}{ Product Code } & \multicolumn{2}{|c|}{ Expiry Date } \\
\hline & $\begin{array}{l}\text { Identifiers acc. } \\
\text { ISO } 15418 \mathrm{r}\end{array}$ & $\begin{array}{l}\text { country code } \\
\text { acc. ISO } 3166\end{array}$ & $\begin{array}{l}\text { Establishment } \\
\text { Number }\end{array}$ & $\begin{array}{l}\text { Unique Donation } \\
\text { Number }\end{array}$ & Identifiers & $\begin{array}{l}\text { Product } \\
\text { Number }\end{array}$ & Identifiers & $\begin{array}{l}\text { Expiry Date } \\
\text { (YYYYMMDD) }\end{array}$ \\
\hline UPN-T & !T & $\begin{array}{l}2 \text { alphabetic } \\
\text { characters }\end{array}$ & $\begin{array}{l}6 \text { numeric } \\
\text { characters }\end{array}$ & $\begin{array}{l}9 \text { numeric } \\
\text { characters }\end{array}$ & $! P$ & $\begin{array}{l}6 \\
\text { numeric }\end{array}$ & !E & $\begin{array}{l}8 \text { numeric } \\
\text { characters }\end{array}$ \\
\hline UPN & $!$ & $\begin{array}{l}3 \text { numeric } \\
\text { characters }\end{array}$ & $\begin{array}{l}3 \text { numeric } \\
\text { characters }\end{array}$ & $\begin{array}{l}6-12 * \text { numeric } \\
\text { characters }\end{array}$ & & $\begin{array}{l}\text { charac- } \\
\text { ters }\end{array}$ & & \\
\hline
\end{tabular}

Fig. 1. The structure of the Eurocode - UPN-T and UPN; the split number required in SEC is part of the Unique Donation Number; ${ }^{*}$ by agreement 9 characters are used in Germany.

THE STRUCTURE OF THE SINGLE EUROPEAN CODE

Fig. 2. The structure of SEC after the initial acronym 'SEC'; it is important to observe that DIS and PIS have to be separated by an empty space or a line break [3].

\begin{tabular}{|c|c|c|c|c|c|c|}
\hline \multicolumn{3}{|c|}{ DONATION IDENTIIICATION SEQUENCE } & \multicolumn{4}{|c|}{ PRODUCT IDENTIICATION SEQUENCE } \\
\hline \multicolumn{2}{|c|}{$\begin{array}{l}\text { EU TISSUE ESTABLISHMENT } \\
\text { CODE }\end{array}$} & \multirow{2}{*}{$\begin{array}{l}\text { UNIQUE } \\
\text { DONATION } \\
\text { NUMBEK }\end{array}$} & \multicolumn{2}{|c|}{ PRODUCT CODE } & \multirow[t]{2}{*}{$\begin{array}{c}\text { SPLIT } \\
\text { NUMBER }\end{array}$} & \multirow[t]{2}{*}{$\begin{array}{l}\text { EXPIRY DATE } \\
\text { (YYYYMMDD) }\end{array}$} \\
\hline $\begin{array}{l}\text { ISO country } \\
\text { code }\end{array}$ & $\begin{array}{l}\text { Tissue estab- } \\
\text { lishment } \\
\text { number }\end{array}$ & & $\begin{array}{c}\text { Product } \\
\text { Coding Sys- } \\
\text { tem identifier }\end{array}$ & $\begin{array}{l}\text { Product } \\
\text { number }\end{array}$ & & \\
\hline $\begin{array}{l}2 \text { alphabetic } \\
\text { characters }\end{array}$ & $\begin{array}{l}6 \text { alpha-nu- } \\
\text { meric charac- } \\
\text { ters }\end{array}$ & $\begin{array}{l}13 \text { alpha-nu- } \\
\text { meric charac- } \\
\text { ters }\end{array}$ & $\begin{array}{l}1 \text { alphabetic } \\
\text { character }\end{array}$ & $\begin{array}{l}7 \text { alpha-nu- } \\
\text { meric charac- } \\
\text { ters }\end{array}$ & $\begin{array}{l}3 \text { alpha-nu- } \\
\text { meric charac- } \\
\text { ters }\end{array}$ & $\begin{array}{l}8 \text { numeric } \\
\text { characters' }\end{array}$ \\
\hline
\end{tabular}

from human origin. With the utilization of the different Eurocode data structures, several processes like the documentation, the data exchange during distribution, the lookback opportunities as well as the processing in IT systems will be improved. Eurocode works together with all other parties interested in this field and supports users during the implementation.

\section{Eurocode and Tissue Coding}

In 2007, Eurocode decided to augment the system, originally created for blood products with code structures for tissues and cells. This was mainly necessary for the product codes. Thus, one new product qualifier as well as several new modifications, storage mediums, and temperatures in the qualifier-describing tables had to be added to the existing data structure.

As a result of discussions in the Single European Code (SEC) implementation group, it became clear that the authorities prefer the country code in the alphabetic form of ISO 3166-1 [8]. For this reason, Eurocode created a new form for the unique product identification of tissues, the UPN-T (fig. 1).

\section{Aims of EU Directives for Cells and Tissues}

The EU described the objectives of coding of cells and tissues in Commission Directives 2004/23/EC and 2006/86/EC as follows:

'Member States shall ensure that all tissues and cells procured, processed, stored or distributed on their territory can be traced from the donor to the recipient and vice versa. This traceability shall also apply to all relevant data relating to products and materi- als coming into contact with these tissues and cells. Member States shall ensure the implementation of a donor identification system which assigns a unique code to each donation and to each of the products associated with it. The Commission, in cooperation with the Member States, shall design a single European coding system to provide information on the main characteristics and properties of tissues and cells' [1].

Directive 2006/86/EC determines the information to be included in the European coding system. A unique ID number and identification of the tissue establishment for donation identification is required as well as a product code in a basic nomenclature, a split number (flag), and an expiry date for the product identification [2]. Directive 2015/565/EC describes the complete final structure of the SEC (fig. 2) [3].

\section{Single European Code and Eurocode Data Elements}

EU Directive 2015/565/EC requires the SEC to start with the acronym 'SEC', followed by a donation identification sequence (DIS) and a product identification sequence (PIS), [3]. Both sequences have to be separated by an empty space or a line break. They contain several data elements as displayed in figure 2.

The sequences and data elements of SEC are covered by previously existing Eurocode data elements. The DIS in SEC corresponds to Eurocode Unique Product Identification Number (UPN). The Eurocode UPN can be used in two different formats: i) UPN-T for tissue and cell preparations and ii) UPN for hematopoietic stem cells (fig. 1).

UPN has been widely implemented before the introduction of SEC in Germany as the format for all hematopoietic cells. Stem 
cell establishments did not implement the new format of UPN-T, because this would have required a change of the existing software solutions for hematopoietic stem cells. UPN-T and UPN are used for the internal communication and the exchange within Germany. Software solutions and labels are augmented with SEC, additionally.

\section{Different Aims, Technical Difficulties, and Barcode Format}

It is important to understand that the primary objective of SEC is to cover traceability issues from the authority's perspective. In contrast to the aim of SEC, Eurocode want to improve the safety of the whole process chain around transfusion and transplantation. This difference is the reason for the existence of different product code tables. While Eurocode and ISBT 128 [9] product codes describes the quality of a product with a qualifier structure (a difference in one the qualifiers results in a new product code), SEC enlists all available tissue and cell components only. To avoid that end-users have to check two different systems, a compromise could be found by creating an EU compendium that matches generic EU, Eurocode, and ISBT 128 product codes. This allows all three product coding systems to be used alternatively as part of the SEC structure. Consequently, users can utilize the EU generic code with only basic information, but also other coding systems with comprehensive information about the products.

In addition to the diverse objectives, there are some technical difficulties associated with SEC. SEC lacks a unique identifier. 2015/565/EC requires the utilization of the acronym 'SEC' at the first positions of the code [3], but this acronym is not enlisted in the ISO/IEC15418 for automatic identification and data capture techniques. As a result, anybody can use these letters for different purposes at the beginning of a code. In contrast to that, the uniqueness of all Eurocode data structures is ensured by the primary data identifier '!' in accordance with ISO/IEC 15418 [6].

Another technical challenge for some software solutions is the empty space required between the donation and product sequence of SEC.

A drawback concerning documentation of SEC is the overall length of 44 characters which can lead to mistakes when transferred manually. The Unique Product Number for Eurocode (UPN and UPN-T) has 37 characters and the different elements, like the DIS, the product code, and the expiry date can be printed separately.

Barcodes on the labels containing the SEC is not required by EU Directives, but explicitly allowed by $2015 / 565 /$ EC [3], because it facilitates data transfer. Eurocode and ISBT 128 strongly advise the utilization of the 2D barcode format 'Data Matrix' for this purpose $[6,9]$. Thus, codes from both systems can be processed by software solutions equipped with 2D barcode readers which are able to interpret Data Matrix. Eurocode IBLS provides a software solution to generate, handle, and create Data Matrix barcode and print labels for SEC

\section{Structure and Matching of Single European Code and Eurocode}

SEC comprises 44 characters including the empty space, whereas Eurocode groups the information in several shorter data elements all starting with the primary identifier '!', followed by a secondary identifier. The various data elements of SEC can be matched with data elements from Eurocode; thus if both systems are highlighted on a label, the parts can be matched with the corresponding contents (fig. 3 ).

\section{System Identifier}

ISO/IEC 15418 describes internationally unique system identifiers [10]. Unfortunately, SEC is not enlisted in this ISO and this acronym can be used by other companies or organization without limitation. The primer identifier of Eurocode '?' is enlisted in ISO/ IEC 151418, thus '?' can be used for Eurocode purposes only. A numeric character at second position is used for the unique product number of blood products, the letter ' $\mathrm{T}$ ' at this position means that the unique product number is given to tissue or cell product.

DIS

This is a specific term in SEC and includes the county code, the tissue establishment number, and a consecutive donation number. Both Eurocode and SEC use the county codes from ISO3166-1. SEC and Eurocode prefer for tissues and cells the 2-digit alphabetic, for blood products Eurocode use the 3-digit numeric nomenclature. The tissue establishment number is given by the national authorities and enlisted on the European Coding Platform. The consecutive donation number in SEC is alphanumeric, in Eurocode only numeric.

\section{PIS}

SEC use a letter to mark the start of the PIS and the letter give the information, which coding system was used for the product codes. Directly after the product code, the split number and the expiry date is written in SEC. Eurocode use new data elements for the different parts of the PIS. Thus, the product code starts with the primer identifier '?' and followed by the letter 'P'. After '!'and letter 'E' the expiry date can be found.

\section{EU Coding Platform}

The EU Coding Platform is a helpful tool. A SEC-DIS or -PIS can be written into a blank field, and the 'translation' of the code elements such as country, establishment data, product code 'decoding' is shown. Additionally, the EU Tissue Establishment Compendium details about the establishments including official name, contact data, the responsible Competent Authority, and the authorized activities. Last but not least, the EU Tissue and Cell Product Compendium supply the EUTC generic coding system as a basic product code system as well as the matching of EUTC codes with Eurocode and ISBT 128 product codes [4]. 


\begin{tabular}{|c|c|c|c|c|c|c|c|c|c|}
\hline \multicolumn{10}{|c|}{ - Matching Table - } \\
\hline \multirow[t]{2}{*}{ System } & $\begin{array}{c}1= \\
\text { System- } \\
\text { identifier }\end{array}$ & \multicolumn{4}{|c|}{$\begin{array}{c}\text { Donation Identification Sequence } \\
\qquad \begin{array}{c}2=\text { country code } \\
3=\text { tissue establishment code }\end{array} \\
4=\text { consecutive donation number }\end{array}$} & \multicolumn{4}{|c|}{$\begin{array}{l}\text { Product Identification Sequence } \\
\begin{array}{c}5=\text { secondary identifier product code } \\
6=\text { product code } \\
7=\text { number for split products } \\
8=\text { Expiry Date }\end{array}\end{array}$} \\
\hline & 1 & 2 & 3 & \multicolumn{2}{|r|}{4} & 5 & 6 & 7 & 8 \\
\hline SEC & SEC & $\mathrm{CC}$ & IIIIIII & \multicolumn{2}{|c|}{ NNNNNNNNNNNNN } & B & 0pppppp & sss & eeeeeeee \\
\hline UPN-T & !T & $\mathrm{CC}$ & iiiiii & \multicolumn{2}{|l|}{ nnnnnnnnn } & $! \mathrm{P}$ & pppppp & $*$ & !Eeeeeeee \\
\hline UPN & $!$ & $\mathrm{ccc}$ & iii & \multicolumn{2}{|c|}{ nnnnnnnnn(nnn) } & !P & pppppp & * & !Eeeeeeee \\
\hline \multicolumn{10}{|c|}{ - Prescription of the acronyms - } \\
\hline \multicolumn{2}{|c|}{ Acronym } & \multicolumn{3}{|c|}{ Format } & \multicolumn{5}{|c|}{ Function } \\
\hline \multicolumn{2}{|l|}{ SEC } & \multicolumn{3}{|c|}{3 letters "SEC" } & \multicolumn{5}{|c|}{ identifier required by $2015 / 565 / E C$} \\
\hline \multicolumn{2}{|l|}{ ! } & \multicolumn{3}{|c|}{ exclamation mark } & \multicolumn{5}{|c|}{ primary identifier acc. ISO/IEC 15418} \\
\hline \multicolumn{2}{|l|}{$\mathrm{T}$} & \multicolumn{3}{|c|}{ letter "T" } & \multicolumn{5}{|c|}{ secondary identifier: UPN-T } \\
\hline \multicolumn{2}{|l|}{ C } & \multicolumn{3}{|c|}{2 digits alpha } & \multicolumn{5}{|c|}{ country code acc. ISO 3166-1 } \\
\hline \multicolumn{2}{|l|}{ c } & \multicolumn{3}{|c|}{3 digits numeric } & \multicolumn{5}{|c|}{ country code acc. ISO 3166-1 } \\
\hline \multicolumn{2}{|l|}{ I } & \multicolumn{3}{|c|}{6 digits alphanumeric } & tissue estab & hme & acc. EU TC & & \\
\hline $\mathrm{i}$ & & 6 and 3 & sits num & & UPN-T and & $\mathrm{N}$ ce & tre code & & \\
\hline $\mathrm{N}$ & & 13 digi & Iphanun & & unique don & ion $n$ & mber SEC & & \\
\hline$n$ & & $\begin{array}{l}9 \text { digits } \\
12 \text {, but } \\
\text { in Gerr }\end{array}$ & $\begin{array}{l}\text { umeric (f } \\
\text { by natio } \\
\text { ny) }\end{array}$ & $\begin{array}{l}\text { UPN up to } \\
\text { regulation }\end{array}$ & $\begin{array}{l}\text { consecutive } \\
\text { check chara }\end{array}$ & $\begin{array}{l}\text { rodu } \\
\text { er ac }\end{array}$ & $\begin{array}{l}\text { number in } \\
\text { ISO 7064, } 1\end{array}$ & $\begin{array}{l}\text { ling } s \\
\text { land }\end{array}$ & $\begin{array}{l}\text { t number(flag) and } \\
\text { N-T }\end{array}$ \\
\hline B & & letter " & & & Product Co & ng Sys & em Identifie & or Eur & ode in SEC \\
\hline $\mathrm{P}$ & & letter" & & & secondary i & entifie & for Product & des ir & urocode \\
\hline$p$ & & 6 digits & meric & & $\begin{array}{l}\text { product coc } \\
\text { to } 7 \text { digits }\end{array}$ & , if us & d in SEC it w & be fille & with a leading " 0 " \\
\hline $\mathrm{s}$ & & 3 digits & hanum & & split numbe & & & & \\
\hline * & & & & & included in & nsec & tive product & mber & \\
\hline$E$ & & letter" & & & secondary i & entifie & for product & piry d & \\
\hline e & & 8 digits & meric & & expiry date & & & & \\
\hline
\end{tabular}

Fig. 3. Matching table of the SEC and relevant Eurocode data elements with prescription of the acronyms of the matching table.
Today the Eurocode system meets all requirements of the EU Directives. The SEC in combination with Eurocode product codes is widely used in Germany; the extension of product code qualifiers for tissue and cell preparations could be done easily. The system gives all necessary opportunities for future extension. As a result of meetings with German authorities, seminars with users and discussions at conferences, many questions of authorities and users could be clarified by the Board and the Technical Committee of Eurocode. Often discussed topics and asked questions were noticed and published in a Frequent Asked Questions (FAQ) document on the Eurocode website.

The utilization of Eurocode Product Codes in SEC in Germany is recommended by the Working Party 'Tissue Preparations' of the German Society of Transfusion Medicine and Immunohematology (DGTI).

\section{Disclosure Statement}

The authors declare no conflicts of interest. 


\section{References}

1 European Commission: Directive 2004/23/EC of the European Parliament and of the Council on setting standards of quality and safety for the donation, procurement, testing, processing, preservation, storage and distribution of human tissues and cells. Officia Journal of the European Union 2004;L102:48-58. http://eur-lex.europa.eu/LexUriServ/LexUriServ.do? uri=OJ:L:2004: 102:0048:0058:en:PDF (last accessed November 7, 2017).

2 European Commission: Commission Directive 2006/86/EC of 24 October 2006 implementing Directive 2004/23/EC of the European Parliament and of the Council as regards traceability requirements, notification of serious adverse reactions and events and certain technical requirements for the coding, processing, preservation, storage and distribution of human tissues and cells. Official Journal of the European Union 2006:L294:32-50. http://eur-lex.europa.eu/LexUriServ/ LexUriServ.do? uri=OJ:L:2006: 294:0032:0050:EN:PDF (last accessed November 7, 2017).
3 European Commission: Commission Directive (EU) 2015/565 of 8 April 2015 amending Directive 2006/86/ EC as regards certain technical requirements for the coding of human tissues and cells. Official Journal of the European Union 2015:L93:43-55. http://eur-lex. europa.eu/legal-content/EN/TXT/PDF/?uri=CELEX:32 015L0565 ¿ from $=F R$ (last accessed November 7, 2017).

4 European Commission: EU Coding Platform - Reference Compendia for the Application of a single European Coding System for Tissues and Cells. https:// webgate.ec.europa.eu/eucoding/reports/te/index.xhtml (last accessed November 7, 2017).

5 European Commission: Directive 2002/98/EC of the European Parliament and of the Council of 27 January 2003 setting standards of quality and safety for the collection, testing, processing, storage and distribution of human blood and blood components and amending Directive 2001/83/EC. Official Journal of the European Union 2002:L33:30-40. http://eur-lex.europa.eu/LexUriServ/LexUriServ.do?uri=OJ:L:2003: 033: 0030: 0040:EN:PDF (last accessed November 7, 2017).
6 Eurocode IBLS e.V.: Technical Specification, Version 2.1.0. 2016. http://www.eurocode.org/guides/structures/ EurocodeTechnicalSpecification-2-1-0.pdf (last accessed November 7, 2017)

7 Eurocode IBLS e.V.: Statute. 2009 http://www.eurocode.org/statutes/english/ECStatute2009.pdf (last accessed November 7, 2017)

8 ISO 3166-1:2013: Country Codes - ISO 3166. 2013 www.iso.org/iso-3166-country-codes.html (last accessed November 7, 2017).

9 ICCBBA:ISBT 128 Standard - Technical Specification, Version 5.8.0. 2017. www.iccbba.org/tech-library/iccbbadocuments/technical-specification (last accessed November 7, 2017).

10 ISO/IEC 15418:2016: Information Technology - Automatic Identification and Data Capture Techniques GS1 Application Identifiers and ASC MH10 Data Identifiers and Maintenance. 2016. www.iso.org/standard/67405.html (last accessed November 7, 2017). 